\title{
Pelatihan Sistem Informasi Berbasis Komputer Bagi Pegawai Kontrak Fakultas Ekonomi Dan Bisnis Universitas Mataram Guna Meningkatkan Kualitas Pekerjaan
}

\author{
Thatok Asmony*, Lilik Handajani, Titiek Herwanti, Endar Pituringsih \\ Fakultas Ekonomi dan Bisnis, Universitas Mataram, Indonesia
}

\begin{abstract}
Kata Kunci: Kualitas SDM, Abstrak: Kegiatan Pelatihan Sistem Informasi Berbasis Komputer ini bertujuan untuk memberikan pemahaman dan melatih pegawai kontrak pada Fakultas Ms Word, Ms Excel, Efektivitas Pelayanan Efisiensi Pekayanan Ekonomi dan Bisnis Universitas Mataram tentang penerapan sistem informasi berbasis komputer dalam melaksanakan pekerjaan guna meningkatkan kualitas pekerjaan. Tujuan lain dari kegiatan ini adalah untuk membantu pegawai kontrak pada Fakultas Ekonomi dan Bisnis Universitas Mataram untuk dapat menghemat waktu dan biaya dalam menyelesaikan pekerjaan. Pada akhirnya kegiatan ini dapat meningkatkan efektivitas dan efisiensi dalam pemberian pelayanan akademik pada Fakultas Ekonomi dan Bisnis Universitas Mataram. Kegiatan pelatihan ini ditujukan pada pegawai kontrak pada Fakultas Ekonomi dan Bisnis Universitas Mataram. Pelaksanaan kegiatan dilakukan dengan pendekatan pemberian materi yang relevan dengan kebutuhan pegawai kontrak dalam pelaksanaan tugas seharihari. Hasil kegiatan ini adalah pegawai kontrak Fakultas Ekonomi dan Bisnis Universitas Mataram dapat memberikan pelayanan akademik yang maksimal melalui penerapan Sistem Informasi Berbasis Komputer.
\end{abstract}

Korespondensi: endar07ringsih@yahoo.co.id

\section{PENDAHULUAN}

Perkembangan teknologi informasi dan komunikasi di era globalisasi semakin pesat dan merambah ke semua sektor kehidupan masyarakat termasuk sektor pendidikan. Penguasaan teknologi informasi dan komunikasi menjadi penting karena setiap pihak yang terlibat di dalamnya dituntut mampu berpartisipasi secara aktif dan terus meningkatkan kemampuan berkompetisi. Informasi yang berkualitas sangatlah penting bagi pengambil kebijakan dalam mengambil suatu keputusan. Informasi yang berkualitas ini tentu terbentuk dari adanya sistem informasi yang dirancang dengan baik. Pemanfaatan sistem informasi yang tepat dan didukung oleh keahlian personil yang mengoperasikannya dapat meningkatkan kinerja organisasi yang bersangkutan.

Perguruan tinggi merupakan sektor strategis yang diharapkan dapat menghasilkan sumber daya manusia yang bermutu dan mampu bersaing di era global. Keadaan persaingan yang cukup kompetitif antar perguruan tinggi menuntut lembaga pendidikan memperhatikan mutu pendidikan dan kelembagaan sehingga mampu serta unggul dalam persaingan tersebut. Perguruan tinggi harus melakukan langkah antisipasi guna menghadapi persaingan yang semakin kompetitif serta bertanggung jawab untuk menggali dan meningkatkan segala aspek pelayanan yang dimiliki, karena sebuah pelayanan yang dimiliki oleh lembaga tertentu akan menjadi gambaran dari kualitas lembaga tersebut, jika pelayanan yang diberikan menurut konsumen itu baik maka sebuah lembaga tersebut bisa dikatakan baik. Tapi sebaliknya jika pelayanan yang dimiliki suatu lembaga buruk maka lembaga tersebut akan dikatakan buruk 
dalam hal pelayanan akademik. Pelayanan akademik dapat diartikan sebagai usaha yang dilakukan oleh perguruan tinggi untuk memberikan kemudahan pada pemenuhan kebutuhan mahasiswa dalam hal yang berkaitan dengan kegiatan akademik.

Baik buruknya pelayanan akademik suatu perguruan tinggi merupakan tanggung jawab semua jajaran perguruan tinggi termasuk pegawai kontrak. Sama halnya dengan perguruan tinggi pada umumnya, masalah yang sering muncul di Fakultas Ekonomi dan Bisnis Universitas Mataram adalah keterbatasan pengelolaan data seperti pengelohan data untuk saringan ujian masuk, pengumuman hasil saringan ujian masuk, sampai proses pendaftaran ulang baik bagi calon mahasiswa baru maupun mahasiswa yang telah menjadi mahasiwa dari Universitas Mataram. Pengolahan data-data tersebut terkadang memerlukan waktu yang cukup lama sehingga menjadi kurang efisien. Oleh karena itu diperlukan penerapan sistem informasi yang terintegrasi agar perguruan tinggi mampu memberikan pelayanan akademik yang unggul dan prima. Integrasi sistem informasi akan mempermudah dan mempercepat proses pekerjaan sehingga tercapai kepuasan pelanggan.

Sistem informasi berbasis komputer mengandung arti bahwa komputer memainkan peranan penting dalam sebuah sistem informasi. Secara teori, penerapan sebuah sistem informasi memang tidak harus menggunakan komputer dalam kegiatannya. Tetapi pada prakteknya tidak mungkin sistem informasi yang sangat kompleks itu dapat berjalan dengan baik jika tanpa adanya komputer. Sistem informasi yang akurat dan efektif, dalam kenyataannya selalu berhubungan dengan istilah computer-based atau pengolahan informasi yang berbasis pada komputer.

Kemampuan komputer mengelola informasi bisnis yang semakin kompleks dijelaskan oleh Reymond McLeod (2004:3) sebagai berikut:

"Informasi adalah salah satu jenis utama sumber daya yang tersedia bagi manajer. Informasi dapat dikelola seperti halnya sumber daya yang lain, dan perhatian pada topik ini bersumber dari dua pengaruh. Pertama, bisnis telah menjadi semakin rumit, dan kedua, komputer telah mencapai kemampuan yang semakin baik."

Dari pendapat diatas dapat disimpulkan bahwa solusi yang dapat diambil untuk menangani dan mengelola informasi bisnis, yang setiap saat dibutuhkan untuk mendukung pengambilan keputusan pihak manajer diperlukan suatu teknologi yang mendukung yaitu komputer. Sistem informasi berbasis komputer merupakan andalan dunia bisnis termasuk kalangan pemerintahan maupun dunia pendidikan. Hal ini juga didukung oleh pendapat Wahyudi (2001:15) yang menyatakan bahwa sistem informasi yang paling efektif saat ini adalah sistem informasi yang pengelolaannya menggunakan perangkat komputer, atau sistem informasi berbasis komputer.

Penerapan sistem informasi berbasis komputer dapat menghasilkan informasi yang berkualitas, sehingga tujuan organisasi (user) dapat tercapai secara effisien dan efektif dengan hasil yang maksimal dalam proses yang optimal dan 5 (lima) hal pokok yang merupakan manfaat dari sistem informasi dalam pengendalian manajemen organisasi, yaitu: penghematan waktu (time saving), penghematan biaya (cost saving), peningkatan efektifitas (effectiveness), pengembangan teknologi(technology development), dan pengembangan personil akuntansi (accounting staff development).

Kunci dari sistem informasi berbasis komputer adalah sistem komputer dan sistem informasi serta yang memanfaatkan sistem informasi berbasis komputer adalah user yang 
bertindak sebagai sistem manajemen. Kemampuan user dalam memanfaatkan sistem informasi berbasis komputer dalam pelaksanaan pekerjaan harian akan memberikan dampak pada kualitas pekerjaan. Jika user mampu memanfaatkan sistem informasi berbasis komputer dengan baik maka kualitas pekerjaan juga akan meningkat. Sebaliknya, jika user tidak mampu memanfaatkan sistem informasi berbasis komputer dalam pelaksanaan pekerjaannya maka kualitas pekerjaan juga akan menurun.

Pada Fakultas Ekonomi dan Bisnis Universitas Mataram pengguna (user) sistem informasi berbasis komputer tidak hanya pegawai tetap melainkan juga pegawai kontrak. Jumlah pegawai kontrak pada Fakultas Ekonomi dan Bisnis Universitas Mataram adalah 81 orang. Pegawai kontrak yang melaksanakan tugas harian menggunakan komputer berjumlah 37 orang yang tersebar pada berbagai program studi. Pada Fakultas Ekonomi dan Bisnis terdapat 6 orang pegawai kontrak, program studi pascasarjana Magister Manajemen 4 orang pegawai kontrak, program studi pascasarjana Magister Akuntansi 1 orang pegawai kontrak, program studi pascasarjana Magister Ilmu Ekonomi 1 orang pegawai kontrak, program studi manajemen 11 orang pegawai kontrak, program studi D-III Pariwisata 6 orang pegawai kontrak, program studi D-III Perpajakan 5 orang pegawai kontrak, dan program studi D-III Akuntansi 3 orang pegawai kontrak.

Mengingat pentingnya peran user dalam penerapan sistem sistem informasi berbasis komputer maka peningkatan kemampuan dan pemahaman user terhadap sistem informasi berbasis komputer menjadi sangat penting. Oleh karena itu, pemberian pelatihan terkait penerapan sistem informasi berbasis komputer bagi pegawai kontrak pada Fakultas Ekonomi dan Bisnis Universitas Mataram perlu dilakukan. Pelatihan akan mampu meningkatkan kompetensi dan kualitas kerja pegawai kontrak yang pada akhirnya akan meningkatkan kualitas layanan di lingkungan Fakultas Ekonomi dan Bisnis Universitas Mataram menjadi lebih baik pula.

\section{METODE KEGIATAN}

Pegawai Kontrak Fakultas Ekonomi dan Bisnis Universitas Mataram masih memiliki pemahaman yang relatif sedikit terkait sistem informasi berbasis komputer. Sementara dalam pekerjaan sehari-hari dibutuhkan penyelesaian yang cepat dan tepat. Oleh sebab itu upaya yang dilakukan untuk meningkatkan pemahaman tentang sistem informasi berbasis komputer bagi pegawai kontrak menjadi penting untuk dilaksanakan guna meningkatkan kualitas pekerjaan.

Beberapa pendekatan dilakukan untuk melaksanakan kegiatan pelatihan sistem informasi berbasis komputer. Adapun pendekatan atau metode yang digunakan dalam kegiatan pelatihan sistem informasi berbasis komputer ini adalah sebagai berikut:

1. Mengidentifikasi kendala, kesulitan dan permasalah yang dihadapi pegawai kontrak dalam pekerjaan;

2. Menyiapkan rancangan materi pendampingan yang aplikatif untuk langsung diterapkan oleh pegawai kontrak;

3. Mengidentifikasi, memilih dan mengumpulkan kendala-kendala yang dihadapi untuk dicarikan solusi atas permasalahan yang dihadapi;

4. Mempersiapkan waktu dan tempat serta jadwal pelaksanaan kegiatan pendampingan sehingga kegiatannya dapat berjalan dengan baik; 
5. Melaksanakan kegiatan pelatihan sistem informasi berbasis komputer dengan menghadirkan pemateri yang mampu memberikan pemahaman yang bisa langsung diaplikasikan;

6. Pendekatan yang dilakukan dalam kegiatan pendampingan ini dilakukan melalui penyampaian materi oleh tim pengabdian, serta pendampingan tentang penerapan sistem informasi berbasis komputer dalam pelaksanaan pekerjaan sehari-hari;

Secara lengkap tahapan kegiatan pelatihan dan edukasi disajikan pada Gambar 1.

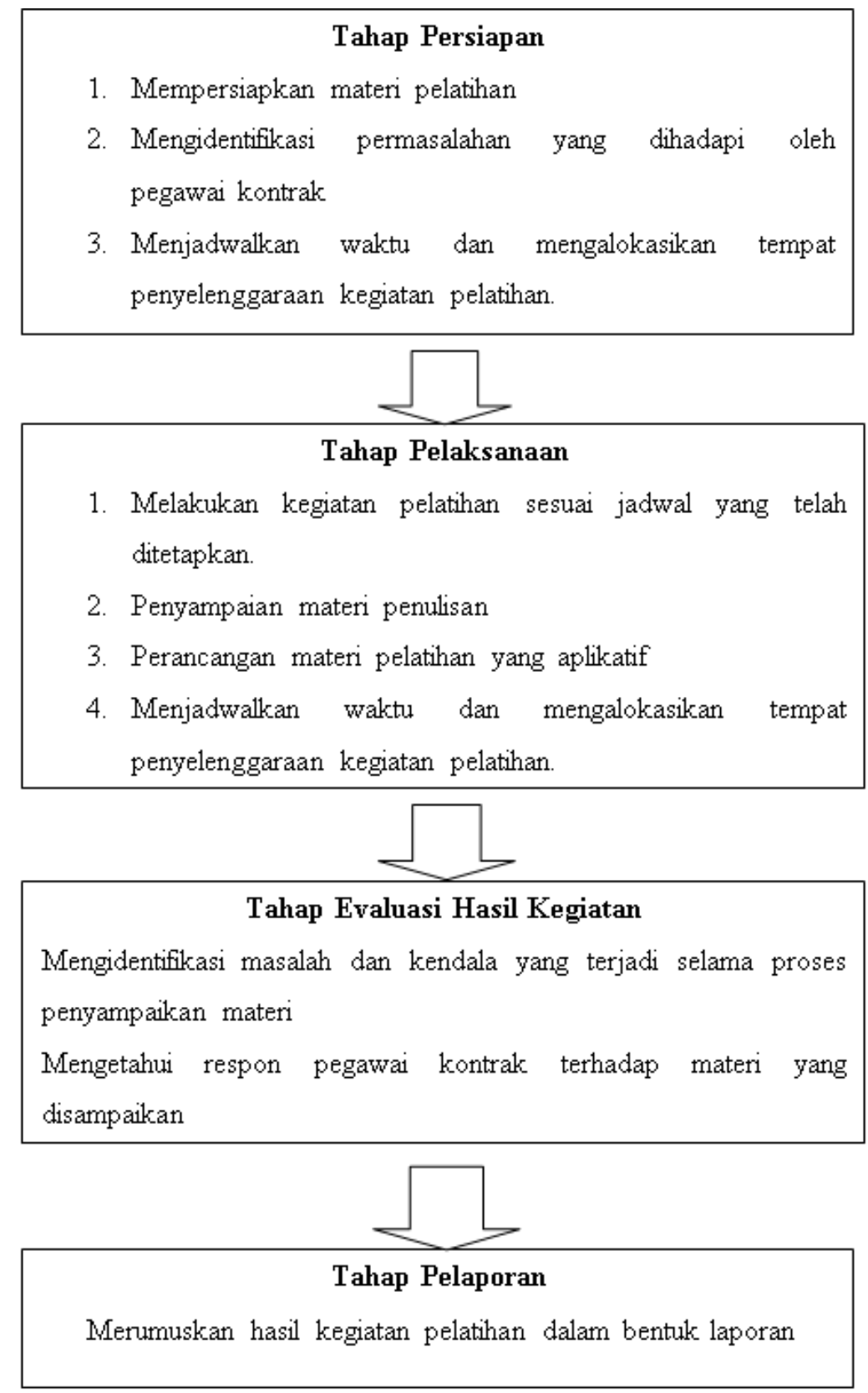

Gambar 1: Tahapan Kegiatan

\section{HASIL DAN PEMBAHASAN}

Kegiatan pengabdian yang berlokasi di Universitas Mataram telah dilakukan pada hari Jumat 23 Agustus 2019 pada pukul 14.00 Wita. Peserta pengabdian dihadiri oleh 21 
pegawai kontrak pada Fakultas Ekonomi dan Bisnis Universitas Mataram. Sebelum kegiatan pengabdian dilakukan, tim telah melakukan pemberitahuan informasi melalui bagian kepegawaian Fakultas Ekonomi dan Bisnis Universitas Mataram. Selanjutnya kegiatan pengabdian ini dilakukan dengan mempresentasikan disertai dengan pelatihan mengenai Sistem Informasi Berbasis Komputer khususnya program Microsoft Word dan Microsoft Excel kepada peserta, dilanjutkan dengan sesi tanya jawab/diskusi antara pemateri dan peserta.

Beberapa materi telah dipersiapkan dalam bentuk handout yang akan dibagikan pada peserta dengan tujuan untuk mempermudah peserta memahami pokok bahasan yang akan diberikan oleh pemateri. Pemberian materi ini akan dilakukan dengan cara presentasi oleh pemateri dengan menampilkan slide powerpoint yang secara lengkap akan disajikan pada lampiran. Adapun materi yang diberikan secara garis besar adalah tentang "Sistem Informasi Berbasis Komputer”, dan secara khusus materi yang disampaikan antara lain:

a. Sistem dan Informasi

Suatu sistem pada dasarnya adalah sekelompok unsur yang erat hubungannya satu dengan yang lain, yang berfungsi bersama-sama untuk mencapai tujuan tertentu. Secara sederhana, suatu sistem dapat diartikan sebagai suatu kumpulan atau himpunan dari unsur, komponen, atau variabel yang terorganisir, saling berinteraksi, saling tergantung satu sama lain, dan terpadu. Menurut Etimologi istilah sistem berasal dari bahasa Yunani, System yang artinya himpunan bagian atau unsur yang saling berhubungan secara teratur untuk mencapai tujuan bersama.

Informasi adalah hasil pemrosesan data yang diperoleh dari setiap elemen sistem tersebut menjadi bentuk yang mudah dipahami dan merupakan pengetahuan yang relevan yang dibutuhkan oleh orang untuk menambah pemahamannya terhadap fakta-fakta yang ada. Informasi bagi setiap elemen akan berbeda satu sama lain sesuai dengan kebutuhannya masing-masing

Sistem dapat dibagi ke dalam beberapa kategori berdasarkan atas dasar keterbukaan dan berdasarkan atas dasar komponen. Atas dasar keterbukaan, sistem terbagi menjadi dua, yaitu pertama, sistem terbuka dimana pihak luar dapat mempengaruhinya. Kedua, Sistem tertutup yaitu sistem yang tidak berhubungan dan tidak terpengaruh dengan sistem luarnya. Sedangkan atas dasar komponen, sistem dapat dibagi menjadi Sistem fisik dan Sistem nonfisik atau konsep. Ada beberapa elemen yang membentuk sebuah sistem, yaitu: tujuan, masukan, proses, keluaran, batas, mekanisme pengendalian dan umpan balik serta lingkungan.

Ada beberapa peranan penting sistem informasi dalam organisasi, antara lain sebagai peningkatan produktivitas, pengurangan biaya, peningkatan pengambilan keputusan, pengembangan aplikasi-aplikasi strategis, mengaitkan perencanaan, pengerjaan, dan pengendalian dalam organisasi, serta mengkoordinasikan subsistem-subsistem dalam organisasi.

\section{b. Sistem Komputer}

Sistem komputer adalah suatu jaringan elektronik yang terdiri dari perangkat lunak dan perangkat keras yang melakukan tugas tertentu (menerima input, memproses input, menyimpan perintah-perintah, dan menyediakan output dalam bentuk informasi). Selain itu 
dapat pula diartikan sebagai elemen-elemen yang terkait untuk menjalankan suatu aktifitas dengan menggunakan komputer. Elemen dari sistem komputer terdiri dari manusianya (brainware), perangkat lunak (software), set instruksi (instruction set), dan perangkat keras (hardware). Dengan demikian komponen tersebut merupakan elemen yang terlibat dalam suatu sistem komputer.

1) Perangkat keras komputer (Hardware) adalah semua bagian fisik komputer, dan dibedakan dengan data yang berada di dalamnya atau yang beroperasi di dalamnya, dan dibedakan dengan perangkat lunak (software) yang menyediakan instruksi untuk perangkat keras dalam menyelesaikan tugasnya.

2) Perangkat lunak (Software) adalah istilah umum untuk data yang diformat dan disimpan secara digital, termasuk program komputer, dokumentasinya, dan berbagai informasi yang bisa dibaca dan ditulis oleh komputer.

3) Brainware adalah setiap orang yang terlibat dalam kegiatan pemanfaatan komputer/sistem pengolahan data. Brainware merupakan sumber inspirasi utama bagi terbentuknya suatu sistem komputer.

c. Sistem Informasi Berbasis Komputer

Computer Based Information System (CBIS) atau Sistem Informasi Berbasis Komputer merupakan suatu sistem pengolah data menjadi sebuah informasi yang berkualitas dan dipergunakan untuk suatu alat bantu pengambilan keputusan. Sistem Informasi "berbasis komputer" mengandung arti bahwa komputer memainkan peranan penting dalam sebuah sistem informasi. Dengan integrasi yang dimiliki antar subsistemnya, sistem informasi akan mampu menyediakan informasi yang berkualitas, tepat, cepat dan akurat sesuai dengan manajemen yang membutuhkannya. Secara teori, penerapan sebuah Sistem Informasi memang tidak harus menggunakan komputer dalam kegiatannya. Tetapi pada prakteknya tidak mungkin sistem informasi yang sangat kompleks itu dapat berjalan dengan baik jika tanpa adanya komputer. Sistem Informasi yang akurat dan efektif, dalam kenyataannya selalu berhubungan dengan istilah computer-based atau pengolahan informasi yang berbasis pada komputer.

Sistem informasi dikembangkan untuk tujuan yang berbeda-beda, tergantung pada kebutuhan bisnis. Skema Sistem Informasi Berbasis Komputer di organisasi, dapat dibagi menjadi beberapa bagian antara lain : Sistem Pemrosesan Transaksi (Transaction Processing Systems), Sistem Otomastisasi Kantor (Office Automation Systems) dan Sistem Kerja Pengetahuan (Knowledge Work Systems), Sistem Informasi Manajemen (Management Information System), Sistem Pendukung Keputusan (Decision Support Systems), Sistem Ahli (Expert System) dan Kecerdasan Buatan (Artificial Intelegent), Sistem Pendukung Keputusan Kelompok (Group Decision Support Systems) dan Sistem Kerja Kolaborasi Dukungan Komputer (Computer-Support Collaborative Work Systems) dan Sistem Pendukung Eksekutif (Executive Support Systems).

Sistem informasi yang tepat, tentunya akan menghasilkan informasi yang cepat, akurat dan dapat dipercaya. Informasi yang cepat, akurat dan dapat dipercaya tersebut sangat diperlukan dalam rangka pengambilan keputusan - keputusan strategis organisasi untuk dapat semakin maju. Penerapan Sistem Informasi Akuntansi berbasis komputer misalnya, merupakan salah satu alternatif jawaban yang tepat jika pihak manajemen menginginkan suatu sumber informasi yang dapat menghasilkan masukan sesuai yang diinginkannya. 
Salah satu program yang sangat penting yang wajib dimiliki dan dikuasai dalam sistem informasi berbasis komputer adalah Microsoft Office. Program ini dapat membantu untuk mengerjakan pekerjaan kantor dengan lebih mudah. Di dalam Microsoft Office terdapat banyak jenis program yang bisa digunakan, dua diantaranya yaitu Microsoft Word dan Microsoft Excel.

Microsoft Word merupakan program pengolahan kata. Sebagai aplikasi pengolahan kata, Microsoft Word memiliki banyak fungsi yang penting. Karena digunakan untuk membuat dokumen kata, maka fungsi Microsoft Word memudahkan dalam mengolah sebuah buku ataupun dokumen seperti surat, artikel, maupun brosur. Fungsi yang dimiliki Microsoft Word antara lain mengenai Heading, pembuatan daftar pustaka, pewarnaan huruf, pengaturan jarak, menggunaan simbol dan penomoran dan masih banyak yang lainnya.

Program lain yang sangat penting untuk dikuasai dalam Microsoft Office adalah Microsoft Excel. Jika Microsoft Word merupakan program yang dirancang untuk melakukan pengolahan kata, maka Microsoft Excel merupakan program yang didesainuntuk melakukan pengolahan angka. Sesuai dengan tugasnya yaitu untuk melakukan pengolahan angka, maka Microsoft Excel dilengkapi dengan berbagai macam fungsi untuk kalkulasi. Selain fungsi kalkulasi, Microsoft Excel juga dilengkapi dengan kelebihan lainnya seperti fungsi logika dan juga sedikit fungsi pengolahan kata.

Setelah proses presentasi yang disampaikan oleh narasumber tentang penggunaan Microsoft Word dan Microsoft Excel, maka sesi kedua adalah memberikan kesempatan pada peserta pelatihan untuk menyampaikan pertanyaan sekaligus melakukan diskusi dua arah antara narasumber dan peserta pelatihan lainnya yang ingin berkontribusi dalam rangka mencarikan solusi atau jawaban atas dipertanyakan yang disampaikan. Adapun beberapa pertanyaan yang diajukan adalah sebagai berikut:

1. Apa manfaat mengaplikasikan program Microsoft Word dan Microsoft Excel bagi pegawai kontrak yang tugas utamanya tidak berhubungan dengan komputer?

2. Bagaimana cara pegawai kontrak meningkatkan kemampuan mengaplikasikan program Microsoft Word dan Microsoft Excel setelah selesai pelatihan, sedangkan beberapa pegawai kontrak tidak bekerja menggunakan komputer?

3. Apakah hanya program Microsoft Word dan Microsoft Excel yang harus dikuasai terkait sistem informasi berbasis komputer?

Dalam menanggapi pertanyaan dari peserta pelatihan, tim pelaksana memberikan penjelasan terkait dengan sistem informasi berbasis komputer. Berikut adalah ringkasan jawaban atas pertanyaan yang diajukan oleh peserta:

1. Secara umum Microsoft Word berguna untuk memudahkan aktivitas pembuatan dokumen kantor seperti surat menyurat, brosur, notulen rapat, serta kontrak kerja. Dengan Microsoft Word pembuatan dokumen-dokumen kantor tersebut menjadi lebih hemat waktu, menghemat kertas, dan menghemat biaya. Sedangkan Microsoft Excel berguna untuk mengolah dan mengatur data - data angka dengan cepat serta mengubah data tersebut ke dalam bentuk diagram atau grafik agar mudah dipahami. Data - data pada perkantoran biasanya berjumlah banyak namun dengan menggunakan Microsoft Excel data - data tersebut dapat diolah dengan lebih cepat melalui fungsi - fungsi Microsoft Excel seperti V Look Up, H Look Up, dan fungsi - fungsi Microsoft Excel lainnya. Pegawai kontrak yang tugas utamanya tidak berhubungan dengan komputer 
tidak dapat merasakan secara langsung manfaat mengaplikasikan kedua program tersebut dalam pekerjaannya. Akan tetapi, kedua program tersebut merupakan dua program dasar yang harus dikuasai di era komputerisasi saat ini. Meskipun saat ini beberapa pegawai kontrak tidak bekerja dengan komputer namun tidak menutup kemungkinan suatu saat akan ditugaskan pada bagian yang berhubungan dengan komputer sehingga pegawai kontrak harus memiliki kemampuan dasar - dasar komputer seperti Microsoft Word dan Microsoft Excel.

2. Pengetahuan tentang komputer yang diperoleh pada saat pelatihan yaitu program Microsoft Word dan Microsoft Excel akan berkembang bila terus dilatih. Sebaliknya, apabila setelah pelatihan pegawai kontrak tidak berlatih maka tidak akan ada perkembangan bahkan pengetahuan yang telah diperoleh akan hilang secara perlahan. Pegawai kontrak yang tidak bekerja dengan menggunakan komputer dapat meningkatkan kemampuan mengaplikasikan Microsoft Word dan Microsoft Excel dengan berlatih di rumah maupun di kantor setelah menyelesaikan tugas utamanya dengan bantuan teman teman yang lebih menguasai program Microsoft Word dan Microsoft Excel.

3. Seperti yang telah dijelaskan sebelumnya, sistem informasi dikembangkan untuk tujuan yang berbeda-beda, tergantung pada kebutuhan organisasi sehingga Sistem Informasi Berbasis Komputer di organisasi dapat dibagi menjadi beberapa bagian yang berbeda. Microsoft Word dan Microsoft Excel bukanlah satu-satunya program yang harus dikuasai karena masih banyak program - program terkait Sistem Informasi Berbasis Komputer yang digunakan dalam prakteknya. Program - program tersebut dibuat sesuai dengan tujuan yang ingin dicapai organisasi. Namun, program Microsoft Word dan Microsoft Excel merupakan program dasar yang harus dikuasai karena kedua program tersebut pasti digunakan pada semua jenis organisasi meskipun organisasi - organisasi tersebut memiliki tujuan yang berbeda.

Secara umum kegiatan ini berjalan dengan sangat baik. Beberapa indikator untuk menilai keberhasilannya adalah tingkat kehadiran peserta pelatihan yang sangat tinggi, animo yang besar untuk mengikuti kegiatan, tanya jawab yang aktif dan interaksi dua arah yang baik selama proses diskusi. Oleh karena itu, diharapkan kegiatan Pelatihan Sistem Informasi Berbasis Komputer Bagi Pegawai Kontrak tetap perlu dilakukan untuk dapat membantu memberikan pemahaman yang baik bagi pegawai kontrak.

\section{KESIMPULAN DAN SARAN}

\section{Kesimpulan}

Berdasarkan kegiatan pengabdian pada masyarakat yang dilakukan di Fakultas Ekonomi dan Bisnis Universitas Mataram, dapat disimpulkan bahwa pegawai kontrak pada Fakultas Ekonomi dan Bisnis Universitas Mataram belum memaksimalkan penerapan system informasi berbasis komputer dalam melaksanakan tugas hariannya. Dengan adanya kegiatan pengabdian ini maka para peserta yang merupakan pegawai kontrak dapat menambah wawasannya terkait pemanfaatan system informasi berbasis computer dalam menunjang pekerjaan sehari-hari sehingga mampu meningkatkan kualitas pekerjaan. 


\section{Saran}

Saran yang bisa ditambahkan untuk kegiatan pengabdian pada masyarakat yang telah dilakukan ini adalah agar pelatihan tetap rutin dilakukan agar meningkatkan pemahaman pegawai kontrak terkait system informasi berbasis computer serta menambah waktu pelatihan agar pelatihan dapat dilakukan dengan lebih maksimal.

\section{Ucapan Terima Kasih}

Tim pengabdian mengucapkan terima kasih kepada Lembaga Penelitian dan Pengabdian kepada Masyarakat (LPPM), Badan Pengkajian dan Pengembangan Ekonomi dan Bisnis (BP2EB), dan Fakultas Ekonomi dan Bisnis melalui sumber dana BLU (PNBP) Universitas Mataram yang telah memberi kesempatan dan bantuan kepada tim pengabdian untuk melakukan kegiatan ini.

\section{DAFTAR PUSTAKA}

Abdul Kadir. 2003. Pengenalan Sistem Informasi. Yogyakarta: Andi Offset.

Aroni Hasan, Hari Kusnanto dan Anis Fuad. 2013. Pengembangan Sistem Informasi Berbasis Komputer untuk Efisiensi Penyelenggaraan Makanan di Instalasi Gizi RS Militer Malang. Jurnal Gizi dan Dietetik Indonesia. Vol. 1 No.1 (22-30).

Jogiyanto HM. 2005. Sistem Teknologi Informasi. Yogyakarta: Andi.

Raymond McLeod, Jr. Dan George Schell. 2004. Sistem Informasi Manajemen (terjemahan). Jakarta: PT Indeks.

Moekijat. 1988. Sistem Informasi Manajemen. Bandung: CV Remaja Karya.

Nugroho E. 2008. Rekayasa Sistem Informasi Manajemen. Tesis. Yogyakarta: UGM.

Rohmani, Asih dan Irfan Abbas. Penerapan Sistem Informasi Berbasis Komputer pada PT. Asuransi Jiwa Bumi Asih Jaya (Studi Kasus: Distrik Tugu Muda Semarang). Universitas Dian Nuswantoro Semarang.

Saliman. 2007. Sistem Informasi Berbasis Komputer (CBIS). Fakultas Ilmu Sosial dan Ekonomi. Universitas Negeri Yogyakarta.

Wahyono T. 2004. Sistem Informasi (Konsep Dasar, Analisis Desain dan Implementasi). Yogyakarta: Graha Ilmu.

Wahyudi Kumorotomo dan Subando Agus Martono. 2001. Sistem Informasi Manajemen. Yogyakarta: Gadjah Mada University Press 